\title{
Assessment of the influence of the shape of steel fibers on the properties of concrete composites
}

\author{
Paweł Helbrych ${ }^{1}$
}

\begin{abstract}
:
The article deals with the issue of the suitability of steel fibers in concrete mixtures. The influence of the shape of steel fibers was also assessed. Two types of steel fibers were analyzed, straight and hooked. The test fibers were made of the same steel and had exactly the same slenderness, diameter and length. The samples were tested after 28 days of maturation, and the mechanical properties that were checked were compressive strength, concrete tensile strength in a bend test and concrete tensile strength when splitting. The results were statistically analyzed and presented in the article.
\end{abstract}

\section{KEYWORDS}

concrete; dispersed reinforcement; steel fibers; shape of the fibers

\section{Introduction}

Due to the increased tensile and compressive strength, concretes reinforced with dispersed fiber are becoming more and more popular in Poland and around the world. In addition, due to the increased fatigue strength and, compared to ordinary concrete, greater abrasion resistance, they are widely used in the construction of slabs on the ground, foundation walls or industrial floors [1-3]. Fibers added to concrete are most often made of steel or plastic, including composite materials. The advantages of steel fibers certainly include the simplicity and speed of production and the possibility of using previously recycled materials [4-7]. According to the following standard [8], steel fibers are straight or deformed fragments of cold drawn steel wire, straight or deformed cut fibers from a sheet, fibers obtained from alloy, cut fibers from cold drawn wire and rolled fibers from steel blocks, suitable for homogeneous mixing with concrete or mortar $[9,10]$.

\section{Research methodology}

The main aim of the research was to determine the influence of the shape of steel fibers on the properties of concrete composites. The tests were carried out on samples made of concrete reinforced with two types of non-galvanized steel fibers and samples made of concrete without the addition of dispersed reinforcement as a control series. The dispersed reinforcement used for the tests is shown in Figure 1, and its geometric parameters are described in Table 1. The reinforcement used for the tests was made of steel with the same tensile strength $\mathrm{R}_{\mathrm{m}}=1000 \div 1020 \mathrm{MPa}$, and with the same slenderness $\lambda=\mathrm{l} / \mathrm{d}=41.6(\mathrm{l}=50 \mathrm{~mm}, \mathrm{~d}=1.2 \mathrm{~mm})$, but it differed in shape. The first type of reinforcement (Fig. 1a) was hook-shaped, while

1 Czestochowa University of Technology, Faculty of Civil Engineering, ul. Akademicka 3, 42-218 Częstochowa, e-mail: pawel.helbrych@pcz.pl, orcid id: 0000-0001-6907-0363 
the second type of reinforcement was straightand and was selected for testing for comparative purposes (Fig. 1b).

\section{Table 1}

Geometric parameters of fibers

\begin{tabular}{|l|l|l|l|l|l|}
\hline Mark & $\begin{array}{l}\text { Length } \\
\mathrm{L}[\mathrm{mm}]\end{array}$ & $\begin{array}{l}\text { Diameter } \\
\mathrm{d}[\mathrm{mm}]\end{array}$ & $\begin{array}{l}\text { Slenderness } \\
(\mathrm{L} / \mathrm{d})\end{array}$ & $\begin{array}{l}\text { Shape } \\
\text { longitudinal }\end{array}$ & $\begin{array}{l}\text { Tensile strength } \\
{[\mathrm{MPa}]}\end{array}$ \\
\hline $\mathrm{P}$ & 50 & 1,2 & 41,6 & straight & $1000 \div 1020$ \\
\hline $\mathrm{H}$ & 50 & 1,2 & 41,6 & hook shape & $1000 \div 1020$ \\
\hline
\end{tabular}

Both the first and the second type of reinforcement were dosed by weight to the concrete mix in three ranges: 10,15 and $20 \mathrm{~kg} / \mathrm{m}^{3}$ (Table 2). The fibers were randomly distributed in the concrete mix and added just after the remaining components of the concrete mix had been mixed. It took no more than 7 minutes to make one sample.

a)

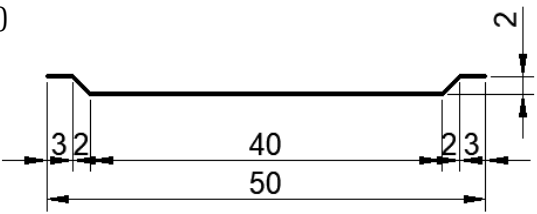

b)

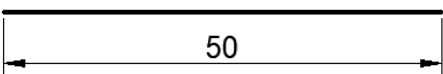

Fig. 1. Dispersed reinforcements used in the tests:

a) hook-shaped reinforcement, b) simple reinforcement

In order to make the tested concretes, components widely used in industry were chosen: Portland cement CEM I $32.5 \mathrm{R}$, gravel mix of $2 \div 8$ and $8 \div 16 \mathrm{~mm}$ fractions, $0 \div 2 \mathrm{~mm}$ fraction sand, tap water and 2 MasterEase 5051 superplasticizer, $5 \%$ by weight of cement. The concrete was designed using the analytical and experimental method, with the $\mathrm{W} / \mathrm{C}$ ratio $=0.45$. It was assumed that the class of concrete used for the tests should not be lower than C30/37, and the designed consistency was S4. All samples were made and tested in the laboratory of the Faculty of Civil Engineering at the Częstochowa University of Technology. Table 2 shows the concrete mix recipe.

\section{Table 2}

Concrete mix recipe

\begin{tabular}{|c|c|c|c|c|c|c|c|}
\hline \multirow{2}{*}{ Ingredients } & \multicolumn{7}{|c|}{ The amount of ingredients per $1 \mathrm{~m}^{3}$ concrete mix $[\mathrm{kg}]$} \\
\hline & SK & S1P & $\mathrm{S} 2 \mathrm{P}$ & S3P & $\mathrm{S} 1 \mathrm{H}$ & $\mathrm{S} 2 \mathrm{H}$ & $\mathrm{S} 3 \mathrm{H}$ \\
\hline Cement CEM I & \multicolumn{7}{|l|}{372} \\
\hline water & \multicolumn{7}{|l|}{168} \\
\hline Sand $0 \div 2 \mathrm{~mm}$ & \multicolumn{7}{|l|}{770} \\
\hline Gravel $2 \div 8 \mathrm{~mm}$ & \multicolumn{7}{|l|}{428} \\
\hline Gravel $8 \div 16 \mathrm{~mm}$ & \multicolumn{7}{|l|}{550} \\
\hline Superplasticizer & \multicolumn{7}{|l|}{9.3} \\
\hline Hook-shaped steel fibers & \multicolumn{4}{|l|}{0} & 10 & 15 & 20 \\
\hline Straight steel fibers & 0 & 10 & 15 & 20 & 0 & & \\
\hline $\mathrm{W} / \mathrm{C}$ & \multicolumn{7}{|l|}{0.45} \\
\hline Consistency class & \multicolumn{7}{|l|}{ S4 } \\
\hline
\end{tabular}

In all test series, 6 cubic samples with dimensions 150x150x150 mm and 3 cubic samples with dimensions $150 \times 150 \times 600 \mathrm{~mm}$ were made. For each series, the consistency class was 
determined by the cone fall method according to PN-EN 12350-2. The samples were disintegrated after $24 \mathrm{~h}$, then, until the tests, they were stored at the temperature of $20 \pm 2^{\circ} \mathrm{C}$ and a relative air humidity equal to $100 \%$.

After 28 days from making the samples, the compressive strength tests according to PN-EN 12390-3 [11] and the tensile strength of the concrete in the bending test - freesupported beam symmetrically loaded with one force according to PN-EN 12390-5 [12] were carried out, in addition, a further strength test was carried out (tensile strength when splitting according to PN-EN 12390-6 [13]). All tests were performed on a Toni Technik type 2030 testing machine in accordance with the requirements of PN-EN 12390-4 at the Faculty of Civil Engineering of the Czestochowa University of Technology.

\section{Results}

In the case of all samples, the surfaces were loaded in the molds, they were not sanded or covered with a leveling layer. The tests were performed within one hour after being moved from the care site. The temperature in the test room was $20^{\circ} \mathrm{C}\left( \pm 5^{\circ} \mathrm{C}\right)$. The surfaces of the platens of the strength test machine were wiped clean and the surfaces of the specimens were checked for contamination or foreign materials that could interfere with the test. No other pressure plates or spacers were used between the sample and the platens. The samples were wiped of excess moisture just prior to testing and placed in the testing machine in such a way that the load was applied perpendicular to the forming direction in the center of the pressure plate of the machine. The loading speed during the tests was constant and amounted to $0.4 \mathrm{MPa} / \mathrm{s}$.

The results of the compressive strength tests are shown in Figure 2. The average compressive strength of the control concrete (SK), determined after 28 days was $\mathrm{f}_{\mathrm{cm}}=41.85 \mathrm{MPa}$, for the series of concretes with the addition of straight dispersed steel reinforcement, it was respectively: series with the addition of $10 \mathrm{~kg} / \mathrm{m}^{3}(\mathrm{~S} 1 \mathrm{P})-\mathrm{f}_{\mathrm{cm}}=49.83 \mathrm{MPa}$, series with the addition of $15 \mathrm{~kg} / \mathrm{m}^{3}(\mathrm{~S} 2 \mathrm{P})-\mathrm{f}_{\mathrm{cm}}=46.1 \mathrm{MPa}$, series with the addition of $20 \mathrm{~kg} / \mathrm{m}^{3}(\mathrm{~S} 3 \mathrm{P})-\mathrm{f}_{\mathrm{cm}}=47.96 \mathrm{MPa}$. For the series of concretes with the addition of steel hooked dispersed reinforcement, it was respectively: series with the addition of $10 \mathrm{~kg} / \mathrm{m}^{3}(\mathrm{~S} 1 \mathrm{H})-\mathrm{f}_{\mathrm{cm}}=49.83 \mathrm{MPa}$, series with the addition of $15 \mathrm{~kg} / \mathrm{m}^{3}(\mathrm{~S} 2 \mathrm{H})-\mathrm{f}_{\mathrm{cm}}=46.1 \mathrm{MPa}$ series with the addition of $20 \mathrm{~kg} / \mathrm{m}^{3}(\mathrm{~S} 3 \mathrm{H})-\mathrm{f}_{\mathrm{cm}}=47.96 \mathrm{MPa}$.

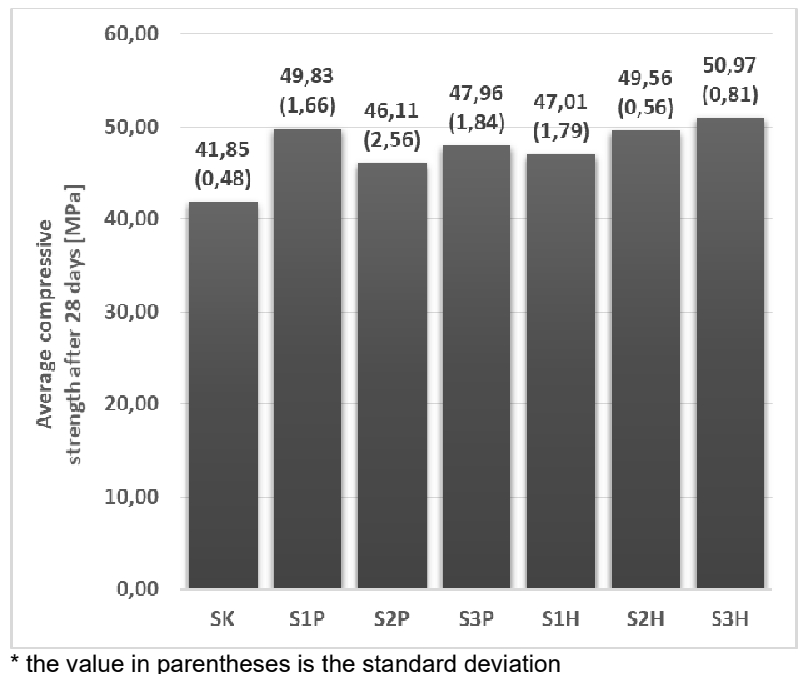

Fig. 2. Compressive strength results according to PN-EN 12390-3 of concretes of all series

The results of concrete tensile strength in the bending test are shown in Figure 3. The average tensile strength of concrete in the bending test of the control concrete (SK), determined after 
28 days was $\mathrm{f}_{\mathrm{ct}}=4.2 \mathrm{MPa}$, for the series of concretes with the addition of straight dispersed steel reinforcement was respectively: series with the addition of $10 \mathrm{~kg} / \mathrm{m}^{3}(\mathrm{~S} 1 \mathrm{P})-\mathrm{f}_{\mathrm{ct}}=5.6 \mathrm{MPa}$, series with the addition of $15 \mathrm{~kg} / \mathrm{m}^{3}(\mathrm{~S} 2 \mathrm{P})-\mathrm{f}_{\mathrm{ct}}=5.5 \mathrm{MPa}$, series with the addition of $20 \mathrm{~kg} / \mathrm{m}^{3}(\mathrm{~S} 3 \mathrm{P})-$ $\mathrm{f}_{\mathrm{ct}}=5,7 \mathrm{MPa}$. For the series of concretes with the addition of steel hook-shaped dispersed reinforcement, it was respectively: series with the addition of $10 \mathrm{~kg} / \mathrm{m}^{3}(\mathrm{~S} 1 \mathrm{H})-\mathrm{f}_{\mathrm{ct}}=5.7 \mathrm{MPa}$, series with $15 \mathrm{~kg} / \mathrm{m} 3(\mathrm{~S} 2 \mathrm{H})-\mathrm{f}_{\mathrm{ct}}=5.5 \mathrm{MPa}$, addition of $20 \mathrm{~kg} / \mathrm{m}^{3}(\mathrm{~S} 3 \mathrm{H})-\mathrm{f}_{\mathrm{ct}}=5.7 \mathrm{MPa}$.

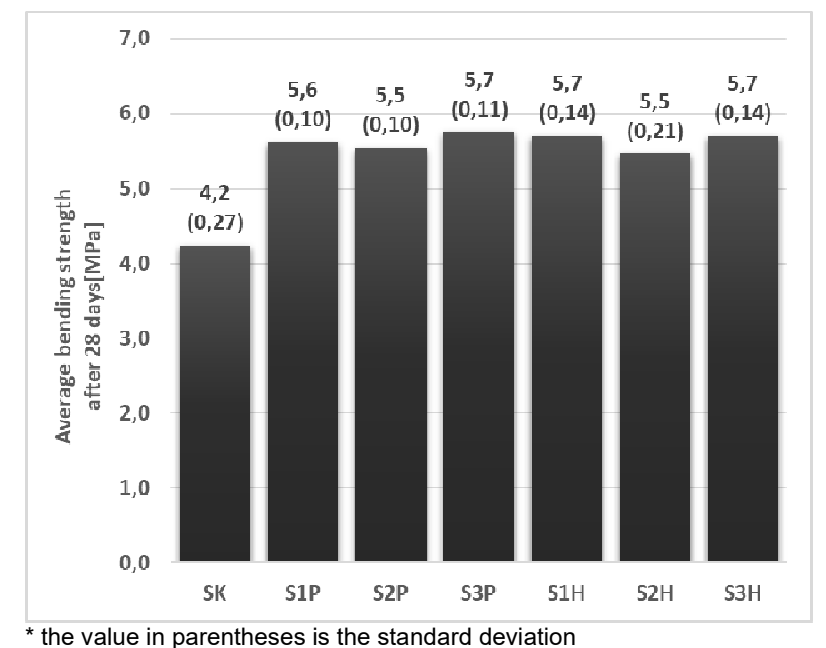

Fig. 3. Concrete tensile strength results in a bending test - a freely supported beam symmetrically loaded with one force according to PN-EN 12390-5 of all concrete series

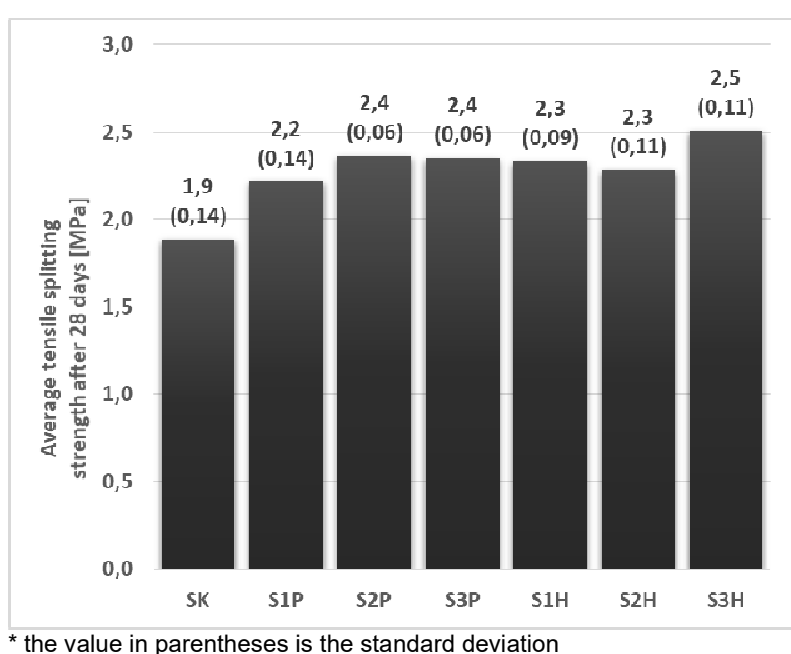

Fig. 4. The results of the tensile strength when splitting according to PN-EN 12390-6 series of concretes

The results of the concrete tensile strength tests when splitting are shown in Figure 4. The average tensile strength of concrete when splitting test concrete (SK), determined after 28 days was $\mathrm{f}_{\mathrm{ct}}=1.9 \mathrm{MPa}$, for a series of concretes with the addition of steel dispersed reinforcement of the straight line was respectively: series with the addition of $10 \mathrm{~kg} / \mathrm{m}^{3}(\mathrm{~S} 1 \mathrm{P})-\mathrm{f}_{\mathrm{ct}}=$ $=2.2 \mathrm{MPa}$, series with the addition of $15 \mathrm{~kg} / \mathrm{m}^{3}(\mathrm{~S} 2 \mathrm{P})-\mathrm{f}_{\mathrm{ct}}=2.4 \mathrm{MPa}$, series with the addition of $20 \mathrm{~kg} / \mathrm{m}^{3}$ (S3P) $-\mathrm{f}_{\mathrm{ct}}=2.4 \mathrm{MPa}$. For the series of concretes with the addition of steel hook- 
shaped dispersed reinforcement, it was respectively: series with the addition of $10 \mathrm{~kg} / \mathrm{m}^{3}$ (S1H) $-\mathrm{f}_{\mathrm{ct}}=2.3 \mathrm{MPa}$, series with the addition of $15 \mathrm{~kg} / \mathrm{m}^{3}(\mathrm{~S} 2 \mathrm{H})-\mathrm{f}_{\mathrm{ct}}=2.3 \mathrm{MPa}$, series with addition of $20 \mathrm{~kg} / \mathrm{m}^{3}(\mathrm{~S} 3 \mathrm{H})-\mathrm{f}_{\mathrm{ct}}=2.5 \mathrm{MPa}$.

\section{Conclusions}

During the research, it was not observed that the type of fibers used had an impact on the spread of the concrete mix, its flow limit or plastic viscosity. The addition of steel fibers to the concrete mix had a positive effect on the mechanical properties of the concrete mixes. On average, the compressive strength in relation to the control mixture increased by $16 \%$, the tensile strength in the bending test by $33 \%$, and the splitting strength by $39 \%$. The test results for the samples with steel reinforcement slightly differed from each other, with the calculated standard deviation of the test, it can be concluded that in the area of the tests performed, the shape of the dispersed steel reinforcement has no significant influence. Moreover, in the scope of the tests carried out, the increased volume fraction of the added fibers, both in the case of straight and hook-shaped fibers, slightly increased the mechanical properties of the concrete tested.

\section{References}

[1] Pietrzak, A. \& Ulewicz, M. (2018) The effect of the addition of polypropylene fibres on improvement on concrete quality. QPI 2018, MATEC Web of Conferences 183, 02011.

[2] Halbiniak, J. (2012) Projektowanie składu betonowego z dodatkiem popiołów lotnych oraz ich wpływ na tempo przyrostu wytrzymałości. Budownictwo o zoptymalizowanym potencjale energetycznym, 2(10), 29-36.

[3] Garbalińska, H.,\& Marciniak, B. (2017). Ocena wytrzymałości na ściskanie betonów różnego rodzaju wyznaczanej na próbkach prostopadłościennych. Zeszyty Naukowe Politechniki Częstochowskiej seria Budownictwo, 23(1).

[4] M. Hsie, C. Tu, P.S. Song, (2008) „Mechanical properties of polypropylene hybrid fiber-reinforced concrete”, „Materials Science and Engineering A”, t. 494, nr 1-2/2008, s. 153-157.

[5] J. Jasiczak, P. Mikołajczak, (2003) „Technologia betonu modyfikowanego domieszkami i dodatkami”, Politechnika Poznańska: Alma Mater, Poznań 2003.

[6] P. Smarzewski, (2017) „Effect of Curing Period on Properties of Steel and Polypropylene Fibre Reinforced Ultra-High Performance Concrete”, „IOP Conference Series: Materials Science and Engineer-ing”, t. 245, $3 / 2017$.

[7] Borowska, S.A., Kosior-Kazberuk, M. (2018). Mrozoodporność betonów ze zbrojeniem rozproszonym. Zeszyty Naukowe Politechniki Częstochowskiej seria Budownictwo, 24(1).

[8] PN-EN 206:2014-04 Beton: Wymagania, właściwości, produkcja i zgodność

[9] Pietrzak, A. (2019). The effect of ashes generated from the combustion of sewage sludge on the basic mechanical properties of concrete. Construction of optimized energy potential, (1), 29-35.

[10] Czajkowska, A., Raczkiewicz, W., Bacharz, M., Bacharz, K. (2020). Influence of maturing conditions of steelfibre reinforced concrete on its selected parameters. Construction of optimized energy potential, (1), 47-54 https://doi.org/10.17512/bozpe.2020.1.05

[11] PN-EN 12390-3:2011 Badania betonu: Wytrzymałość na ściskanie próbek do badań;

[12] PN-EN 12390-5:2011 Badania betonu: Wytrzymałość na zginanie próbek do badań;

[13] PN-EN 12390-6:2011 Badania betonu: Wytrzymałość na rozciąganie przy rozłupywaniu próbek do badań;

[14] PN-EN 1992-1-1:2004 Eurokod 2: Projektowanie konstrukcji z betonu. Część 1-1: Reguły ogólne i reguły dla budynków;

[15] PN-EN 14889-1 Włókna do betonu - Część 1: Włókna stalowe - Definicje, wymagania i zgodność

\section{Ocena wpływu kształtu włókien stalowych na właściwości kompozytów betonowych}

STRESZCZENIE:

Poruszono zagadnienie przydatności włókien stalowych w mieszankach betonowych oraz poddano pod ocenę wpływ kształtu włókien stalowych. Analizowano dwa rodzaje włókien stalowych - proste oraz 
haczykowate. Włókna do badań były wykonane z tej samej stali oraz miały dokładnie tę samą smukłość, średnicę oraz długość. Próbki badano po upływie 28 dni dojrzewania, a właściwości mechaniczne, jakie sprawdzono, to wytrzymałość na ściskanie, wytrzymałość betonu na rozciąganie w próbie zginania oraz wytrzymałość betonu na rozciąganie przy rozłupywaniu. Wyniki poddano analizie statystycznej.

\section{SŁOWA KLUCZOWE:}

beton; zbrojenie rozproszone; włókna stalowe; kształt włókien 